\title{
ANALISIS PENDAPATAN DAN PROSPEK AGRIBISNIS ABALON (HALIOTIS ASININA) DI KABUPATEN KONAWE DAN KOTA KENDARI
}

\author{
Income Analysis and Prospect of Abalone Agribusiness (Haliotis Asinina) in \\ Konawe Regency and Kendari City
}

\author{
Rahmat Arif Adimulya ${ }^{1}$, Onu La Ola ${ }^{2}$ dan Azhar Bafadal ${ }^{2}$ \\ ${ }^{1}$ Mahasiswa Program Studi Magister Agribisnis Universitas Halu Oleo \\ ${ }^{2}$ Program Studi Magister Agribisnis Universitas Halu Oleo
}

\begin{abstract}
Abalone (Haliotis asinina) is one of the economically valuable commodities of fishery. Abalon products have a high prices and market demand especially to export. This condition, abalone businesses should get a high income for them. The research was to analyze the abalone business doer in each level and developing prospect of abalone agribusiness in Southeast Sulawesi based on the relationship between agribusiness sub-system and the income gained. Respondents and population of research was the whole abalone business comprised of fishermen, cultivator, collector venders, and inter venders. Descriptive analysis is used to find out the relationship of abalone agribusiness sub-system, while income analysis is used to find out the income of abalone agribusiness. To see the prospect of abalone agribusiness the analysis of descriptive and income is used. Result of the research shown that the relationship of abalone agribusiness has not well integrated. The income gained by fishermen per season is Rp.309.211,- , and the collector vender is Rp.9.830.734,-, while the income of inter vender of province is Rp.12.282.976,-. From the result of the analysis can be concluded that abalone agribusiness has an average prospect to be developed in Konawe Regency.
\end{abstract}

Keywords: abalone, agribusiness, income analysis, prospect of abalone

\begin{abstract}
ABSTRAK
Abalon (Haliotis asinina) adalah salah satu produk perikanan yang bernilai ekonomis. Produk abalon memiliki harga jual yang mahal dan permintaan yang tinggi, khususnya pada pasar ekspor. Seharusnya agribisnis abalon dapat meningkatkan pendapatan masyarakat khususnya nelayan. Penelitian ini bertujuan untuk (1) Mengkaji keterkaitan antar subsistem agribisnis abalon di Sultra; (2) Menganalisis pendapatan yang diperoleh pelaku bisnis abalon pada setiap tingkatan; (3) Mengkaji prospek agribisnis abalon berdasarkan keberadaan aspek-aspek yang mendukung agribisnis abalon di Sultra. Responden dalam penelitian ini adalah seluruh pelaku bisnis abalon yang terdiri dari 65 orang nelayan, 2 orang pembudidaya, 4 orang pengumpul desa dan 3 orang pedagang antar provinsi. Penentuan responden dilakukan dengan metode snow ball sampling. Keterkaitan antar subsistem agribisnis abalon dianalisis secara deskriptif, sedangkan untuk menghitung pendapatan dalam bisnis abalon digunakan analisis pendapatan. Untuk melihat prospek pengembangan agribisnis abalon maka digunakan analisis secara deskriptif dan analisis pendapatan. Hasil analisis menunjukan bahwa keterkaitan antar subsistem agribisnis abalon belum terintegrasi dengan baik. Pendapatan yang diperoleh nelayan adalah sebesar Rp. 309.211,- per bulan, pendapatan pedagang pengumpul desa Rp. 9.830.734,- per bulan, sedangkan pendapatan pedagang antar provinsi sebesar Rp. 12.282.976,- per bulan. Dari hasil analisis juga dapat disimpulkan bahwa agribisnis abalon cukup prospek untuk dikembangkan di Kabupaten Konawe dan Kota Kendari.
\end{abstract}

Kata Kunci: abalon, agribisnis, analisis pendapatan, prospek agribisnis 
PENDAHULUAN

\section{Latar Belakang}

Total ekspor kekerangan Indonesia pada tahun 2011 mencapai 2.660 ton dengan nilai ekspor US\$15,5 juta. Sebanyak $2 \%$ atau 60 ton diantaranya adalah produk abalon dengan nilai US\$ 500 ribu (KKP, 2012). Abalon menjadi salah satu produk perikanan laut yang memiliki nilai ekonomis. Pangsa pasar abalon tidak hanya terbatas di dalam negeri namun juga di luar negeri.

Permintaan komoditas abalon di pasar internasional terus mengalami peningkatan (Estes et al, 2005). Peningkatan permintaan abalon biasanya selalu diikuti dengan peningkatan harga. Selain itu, tingginya harga abalon juga disebabkan oleh terbatasnya volume produksi. Di dalam negeri, pada tahun 2012 harga abalon segar di tingkat nelayan berkisar antara Rp.50.000-150.000 per kg sedangkan abalon yang telah diolah berkisar antara Rp200.000-300.000 per kg. Di pasar internasional, harga abalon segar berkisar antara US\$22-44 per kg dan terus mengalami peningkatan. Jika telah diolah (salted and dried) harganya bisa mencapai US\$125 per kg (McBride dan Conte, 1994).

Baik di dalam negeri maupun di luar negeri, produk abalon telah memiliki pasar tersendiri terutama dari etnis Tionghoa. Selama ini berapa pun jumlah abalon yang dihasilkan oleh nelayan selalu terserap oleh pasar baik dalam negeri maupun untuk ekspor (Estes, 2005).

Harga yang tinggi dan permintaan pasar yang terus meningkat mengindikasikan bahwa usaha budidaya abalon memiliki prospek untuk dikembangkan (Fermin dan Encena, 2009). Untuk mengetahui prospek pengembangan suatu usaha maka indikator-indikator yang digunakan selain indikator finansial (pendapatan, R/C, BEP) juga indikator fisik, sosial dan potensi pasar Soeharto (1999).

\section{Rumusan Masalah}

Rumusan masalah dalam penelitian ini adalah :

1) Berapa pendapatan yang diperoleh pelaku usaha abalon pada setiap tingkatan usaha di Kabupaten Konawe dan Kota Kendari?

2) Bagaimana prospek pengembangan agribisnis abalon berdasarkan aspekaspek yang mendukung agribisnis abalon di Kabupaten Konawe dan Kota Kendari?

\section{Tujuan Penelitian}

Berdasarkan rumusan masalah tersebut di atas maka tujuan penelitian ini adalah:

1) Untuk menganalisis pendapatan yang diperoleh pelaku usaha abalon pada setiap tingkatan usaha.

2) Untuk mengkaji prospek agribisnis abalon berdasarkan aspek-aspek yang mendukung agribisnis abalon di Kabupaten Konawe dan Kota Kendari. 
Manfaat Penelitian

Manfaat yang diharapkan dari penelitian ini adalah :

1) Sebagai sumber informasi bagi pelaku bisnis mengenai gambaran kondisi sistem agribisnis abalon di Kabupaten Konawe dan Kota Kendari.

2) Sebagai sumber informasi mengenai pola keterkaitan antar subsistem agribisnis abalon di Kabupaten Konawe dan Kota Kendari.

3) Sebagai bahan pertimbangan pemerintah dalam kebijakan pegembangan agribisnis abalon di Kabupaten Konawe dan Kota Kendari.

4) Menjadi bahan referensi bagi penelitianpenelitaian berikutnya.

\section{METODE PENELITIAN}

\section{Analisis Pendapatan Usaha Abalon}

Rumus pendapatan yang digunakan adalah:

Pendapatan $=$ Penerimaan - Biaya Total

$$
=\left(P_{Y} \cdot Y\right)-(F C+V C)
$$

dimana:

Py = Harga abalon $(\mathrm{Rp} / \mathrm{kg})$

$\mathrm{Y} \quad=$ Jumlah abalon (kg/tahun)

$\mathrm{FC}=$ Biaya tetap/fixed cost (Rp/tahun)

VC = Biaya variabel/variabel cost (Rp/tahun)

Kriteria usaha yang prospek menurut Soeharto (1999) yaitu; (a) dapat menghasilkan pendapatan yang cukup untuk membayar semua alat atau bahan yang diperlukan; (b) dapat menghasilkan pendapatan yang dapat dipergunakan untuk membayar bunga modal yang dipergunakan dalam usahatani tersebut, baik modal sendiri maupun modal pinjaman; (c) dapat membayar upah tenaga kerja petani dengan keluarganya yang dipergunakan dalam usahatani tersebut secara layak.

Pendapatan yang diperoleh kemudian dibandingkan dengan Upah Minimum Provinsi (UMP) yang berlaku di Sulawesi Tenggara. Hal ini bertujuan untuk dapat melihat sejauh mana usaha yang dilakukan tersebut dapat menghasilkan pendapatan yang dapat digunakan untuk memenuhi kebutuhan hidup yang layak. Sesuai ketetapan Gubernur Provinsi Sulawesi Tenggara Tahun 2014.

\section{Prospek Agribisnis Abalon Di Sultra}

Prospek agribisnis abalon di Kabupaten Konawe dan Kota Kendari dianalisis secara deskripsi berdasarkan aspek-aspek yang mendukung pengembangan agribisnis abalon di Sultra. Aspek-aspek pendukung agribisnis abalon menurut Fermin dan Encena (2009) adalah aspek teknis, aspek ekonomi, aspek finansial dan aspek kebijakan.

Aspek-aspek pendukung tersebut terbatas pada beberapa hal sebagai berikut:

1. Aspek teknis yaitu ketersediaan fasilitas pembibitan abalon, keterampilan dalam kegiatan pembenihan abalon, wilayah perairan yang luas untuk budidaya dan ketersediaan rumput laut sebagai pakan alami abalon. 
2. Aspek ekonomi yaitu pendapatan pelaku bisnis abalon dan potensi pasar internasional (permintaan dan harga).

3. Aspek finansial yaitu akses pelaku bisnis abalon terhadap lembaga keuangan (Bank).

4. Aspek kelembagaan yaitu dukungan pemerintah dan lembaga swasta terhadap pengembangan agribisnis abalon.

Hasil deskripsi dari aspek-aspek di atas kemudian di kelompokkan menjadi faktor kekuatan (strength), kelemahan (weakness), peluang (opportunity) dan ancaman (threat) menurut Fermin dan Encena (2009). Secara sederhana pengelompokkannya dapat dilihat pada Tabel 1.

Tabel 1. Format Prospek Agribisnis Abalon di Kab. Konawe dan Kota Kendari Berdasarkan Kekuatan, Kelemahan, Peluang dan Ancaman yang Dimiliki

\begin{tabular}{|c|c|}
\hline $\begin{array}{l}\text { Kekuatan } \\
\text { (Strength) }\end{array}$ & $\begin{array}{l}\text { Kelemahan } \\
\text { (Weakness) }\end{array}$ \\
\hline 1. Kekuatan 1 & 1. Kelemahan 1 \\
\hline 2. Kekuatan 2 & 2. Kelemahan 2 \\
\hline 3. Dst. & 3. Dst. \\
\hline $\begin{array}{c}\text { Peluang } \\
\text { (Opportunity) }\end{array}$ & $\begin{array}{c}\text { Ancaman } \\
\text { (Threat) }\end{array}$ \\
\hline 1. Peluang 1 & 1. Ancaman 1 \\
\hline 2. Peluang 2 & 2. Ancaman 2 \\
\hline 4. Dst. & 3. Dst. \\
\hline
\end{tabular}

\section{HASIL DAN PEMBAHASAN}

\section{Pendapatan dalam Usaha Penangkapan Abalon}

Untuk mengetahui pendapatan yang diperoleh dalam usaha penangkapan abalon maka dilakukan analisis terhadap intensitas penangkapan per musim, rata-rata produksi per musim, biaya total per musim, dan penerimaan total per musim.

Intensitas Penangkapan dan Rata-rata Produksi per Musim

Intensitas penangkapan dan rata-rata hasil tangkapan tertinggi terjadi pada musim Angin Muson Timur yaitu 20 trip selama satu musim dengan hasil tangkapan $34,8 \mathrm{~kg}$. Hal ini sesuai dengan hasil penelitian Hadijah, et al. (2008) yang menunjukan bahwa jumlah abalon yang tertangkap lebih banyak terjadi pada bulan Mei, Juni dan Agustus. Maliao et al. (2003) dalam penelitiannya tentang kepadatan abalon menunjukan bahwa kepadatan abalon di perairan tertutup pada bulan Mei cukup tinggi. Lebih jelasnya dapat dilihat pada Tabel 2.

Tabel 2. Intensitas Penangkapan dan Ratarata Produksi Abalon per Musim

\begin{tabular}{|l|c|c|}
\hline \multicolumn{1}{|c|}{ Musim } & $\begin{array}{c}\text { Intensitas } \\
\text { Penangkapan } \\
\text { per Musim per } \\
\text { Orang } \\
\text { (Trip) }\end{array}$ & $\begin{array}{c}\text { Rata-rata } \\
\text { Produksi } \\
\text { per Musim } \\
\text { per Orang } \\
\text { (Kg) }\end{array}$ \\
\hline $\begin{array}{l}\text { Angin Muson } \\
\text { Timur }\end{array}$ & 20 & 34,8 \\
\hline $\begin{array}{l}\text { Angin Muson } \\
\text { Barat }\end{array}$ & 8 & 13,9 \\
\hline Pancaroba & 10 & 4,6 \\
\hline Rata-rata & 13 & 17,8 \\
\hline
\end{tabular}

Jumlah penangkapan abalon dalam satu bulan adalah empat kali trip, dengan rata-rata penangkapan satu kali dalam satu minggu. Hal ini dikarenakan penangkapan per minggu lebih efisien dari pada penangkapan per hari. 
Nelayan beranggapan bahwa hasil tangkapan per minggu lebih banyak dengan biaya operasional yang lebih kecil, namun hal ini perlu penelitian lebih lanjut.

Intensitas penangkapan per bulan dan jumlah hasil tangkapan per trip pada musim Angin Muson Barat sama dengan penangkapan pada musin Angin Muson Timur yaitu empat kali trip dalam satu bulan (satu kali seminggu) dengan rata-rata hasil tangkapan 1,7 per orang per trip. Namun intensitas penangkapan lebih sedikit yaitu hanya delapan kali selama satu musim. Hal disebabkan karena jumlah bulan penangkapan efektif hanya dua bulan saja yaitu bulan Januari dan Februari. Bulan lainnya pada musim ini (Oktober, November, Desember dan Maret) sudah termasuk dalam musim Pancaroba. Sehingga jumlah hasil tangkapan selama satu musim adalah 4,6 kg. Lebih jelasnya tentang pembagian musim angin dalam satu tahun dapat dilihat pada Gambar 1.

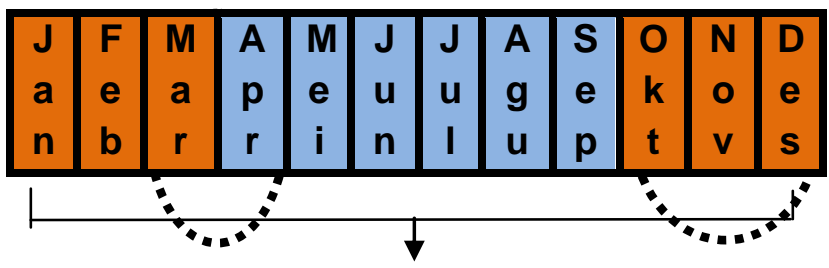

Keterangan Gambar:

\section{Siklus 1 Tahun}

Angin Muson Barat

Angin Muson Timur

Pancaroba

Gambar 1. Pembagian Musim Angin dalam Satu Tahun (Tjasyono dan Bannu, 2003)

Intensitas penangkapan per bulan dan jumlah hasil tangkapan per trip pada musim Pancaroba lebih sedikit dibandingkan dengan penangkapan per bulan pada musim Angin Muson Timur dan musim Angin Muson Barat. Pada musim Pancaroba penangkapan efektif hanya dapat dilakukan sebanyak dua kali dalam satu bulan dengan rata-rata hasil tangkapan 0,5 kg per trip. Intensitas penangkapan selama musim Pancaroba adalah 10 kali trip dengan total hasil tangkapan 4,6 kg.

Total hasil tangkapan selama musim Pancaroba lebih sedikit karena instensitas penangkapan per bulan lebih rendah dan hasil tangkapan per trip lebih sedikit. Rendahnya intensitas penangkapan pada musim Pancaroba disebabkan karena kondisi cuaca yang tidak memungkinkan untuk melakukan penangkapan abalon yaitu tingginya gelombang dan angin yang kencang. Hal ini sesuai dengan penyataan Tjasyono dan Bannu, (2003) bahwa musim Pancaroba ditandai dengan tingginya frekuensi badai, hujan sangat deras disertai guruh dan angin kencang.

\section{Penerimaan}

Berdasarkan hasil penelitian menunjukan bahwa produksi nelayan berkisar antara 4,6-34,8 kg per musim dengan ratarata produksi $17,8 \mathrm{~kg}$ per musim. Harga jual abalon segar yang berlaku adalah Rp.55.000 per $\mathrm{kg}$, dimana harga ini adalah harga yang disepakati oleh nelayan dengan pembeli untuk campuran abalon induk dan abalon muda.

Penerimaan responden dari usaha ini berkisar antara Rp.253.000-Rp.1.914.000 per 
musim. Rata-rata penerimaan adalah sebesar Rp.977.167 per musim. Adanya variasi jumlah penerimaan responden disebabkan karena jumlah produksi yang dihasilkan masingmasing responden berbeda. Jumlah produksi yang berbeda dipengaruhi oleh metode penangkapan dan musim yang berlaku.

\section{Biaya}

Biaya tetap dalam usaha penangkapan abalon misalnya biaya perawatan perahu dan biaya penyusutan alat tangkap yang dihitung tiap bulan. Adapun biaya tidak tetap didefinisikan sebagai biaya yang jumlahnya dipengaruhi oleh produksi yang dihasilkan.

Biaya tidak tetap dalam penangkapan abalon adalah biaya bahan bakar minyak (BBM), biaya makan, aksesoris (rokok dan minuman energi) yang digunakan selama satu musim (rata-rata 13 kali trip). Upah tenaga kerja dalam usaha ini digolongkan dalam komponen biaya tidak tetap karena besarnya upah tenaga kerja yang diterima sesuai dengan hasil tangkapan nelayan.

Biaya investasi mencakup biaya pembelian perahu, mesin dan alat tangkap khusus abalon. Perahu bermesin yang digunakan dalam operasional penangkapan abalon juga digunakan pada penangkapan ikan dan hasil laut lainnya, sehingga dalam perhitungan biaya investasi untuk penangkapan abalon hanya dimasukkan 50\% dari harga pembelian. Rincian mengenai besarnya penggunaan biaya dalam usaha penangkapan abalon dapat dilihat pada Tabel 3.

Tabel 3. Rata-rata Biaya Operasional per Musim dalam Usaha Penangkapan Abalon

\begin{tabular}{|l|r|}
\hline \multicolumn{1}{|c|}{ Komponen Biaya } & $\begin{array}{r}\text { Nilai rata-rata } \\
\text { (Rp/musim) }\end{array}$ \\
\hline 1. Biaya Tetap & $\mathbf{8 9 . 1 8 7}$ \\
\hline - $\begin{array}{l}\text { Biaya perawatan } \\
\text { perahu }\end{array}$ & 53.846 \\
\hline - Biaya penyusutan & 35.341 \\
\hline 2. Biaya tidak tetap & $\mathbf{5 7 8 . 7 6 9}$ \\
\hline - BBM (13 Trip) & 233.846 \\
\hline - Makanan (13 Trip) & 204.615 \\
\hline - Biaya lain-lain (13 Trip) & 140.308 \\
\hline 3. Biaya Total & $\mathbf{6 6 7 . 9 5 6}$ \\
\hline
\end{tabular}

3. Pendapatan

Pendapatan yang dimaksud dalam penelitian ini adalah pendapatan yang diperoleh dari hasil pengurangan antara penerimaan total dengan seluruh biaya yang dikeluarkan dalam proses penangkapan abalon. Pendapatan yang diperoleh akan memberikan gambaran tentang keadaan usaha penangkapan abalon di Kecamatan Soropia. Rincian mengenai total biaya yang digunakan, total penerimaan dan pendapatan yag diperoleh nelayan dapat dilihat pada Tabel berikut :

Tabel 4. Pendapatan Nelayan Abalon

\begin{tabular}{|c|r|}
\hline Rincian & $\begin{array}{c}\text { Nilai rata-rata } \\
\text { (Rp/musim) }\end{array}$ \\
\hline Penerimaan Total (TR) & 977.167 \\
\hline
\end{tabular}




\begin{tabular}{|l|r|}
\hline Biaya Total (TC) & 667.956 \\
\hline Pendapatan= TR -TC & $\mathbf{3 0 9 . 2 1 1}$ \\
\hline
\end{tabular}

Jika mengacu pada kriteria usaha yang prospek menurut Soeharto (1999), maka dapat dikatakan bahwa usaha ini tidak prospek. Pendapatan nelayan dari hasil penangkapan abalon sangat rendah jika dibandingkan dengan nilai UMP yang berlaku. Hal ini dikarenakan posisi tawar nelayan yang sangat lemah dalam bisnis abalon. Dalam bisnis abalon, nelayan tidak bisa menetapkan harga.

\section{Pendapatan dalam Usaha Pengolahan Abalon}

\section{Penerimaan}

Hasil penelitian menujukan bahwa produksi abalon kering hasil olahan berkisar antara 85,4-156,6 kg per musim dengan ratarata produksi $115,7 \mathrm{~kg}$ per musim. Harga jual abalon kering yang berlaku di Kota Kendari adalah Rp.250.000 per kg. Sehingga penerimaan responden dari usaha ini berkisar antara Rp.21.360.000-Rp.39.160.000 per musim. Rata-rata penerimaan adalah sebesar Rp.28.925.000 per musim. Adanya variasi jumlah penerimaan responden disebabkan karena jumlah produksi yang dihasilkan masing-masing responden berbeda. Jumlah produksi yang berbeda dipengaruhi oleh pasokan abalon segar dari nelayan yang juga berbeda-beda.

\section{Biaya}

Rincian mengenai besarnya penggunaan biaya dalam usaha pengolahan abalon dapat dilihat pada Tabel 5.

Tabel 5. Rata-rata Biaya Produksi dalam Usaha Pengolahan Abalon di Kecamatan Soropia, Tahun 2014

\begin{tabular}{|l|r|}
\hline \multicolumn{1}{|c|}{ Komponen Biaya } & $\begin{array}{c}\text { Nilai rata-rata } \\
\text { (Rp/musim) }\end{array}$ \\
\hline 1. Biaya Tetap per Musim*) & $\mathbf{7 3 1 . 8 5 2}$ \\
\hline • Biaya perawatan alat & 500.000 \\
\hline - Biaya penyusutan & 231.852 \\
\hline $\begin{array}{l}\text { 2. Biaya Tidak Tetap per } \\
\text { Musim*) }\end{array}$ & $\mathbf{1 8 . 9 6 3 . 7 5 0}$ \\
\hline - Total harga abalon & 15.908 .750 \\
\hline - segar & 100.000 \\
\hline - Barga bahan-bahan & 100.000 \\
\hline - Upah Tenaga Kerja & 2.800 .000 \\
\hline 3. Biaya Total & $\mathbf{1 9 . 6 9 5 . 6 0 2}$ \\
\hline
\end{tabular}

Ket: *) satu musim rata-rata empat bulan

Besarnya biaya total yang dikeluarkan oleh pedagang pengumpul desa adalah sebesar Rp.19.695.602 per musim. Komponen biaya tidak tetap secara keseluruhan merupakan biaya terbesar yang dikeluarkan oleh nelayan yaitu $96,28 \%$ dari keseluruhan biaya yang dikeluarkan. Harga bahan baku abalon segar merupakan biaya terbesar yang dikeluarkan pada komponen biaya ini yaitu Rp.15.908.750 per musim. Harga bahan dan biaya pengiriman adalah biaya terkecil dalam usaha pengolahan abalon yaitu Rp.100.000 
per musim, yang berasal dari komponen biaya tidak tetap

\section{Pendapatan}

Berdasarkan hasil penelitian diketahui bahwa rata-rata pendapatan dari hasil pengolahan abalon kering adalah sebesar Rp.6.645.734 per bulan. Lebih jelasnya tentang penerimaan total, biaya total dan pendapatan dari usaha pengolahan abalon kering di Kecamatan Soropia dapat dilihat pada Tabel 6.

Tabel 6. Pendapatan dari Usaha Pengolahan Abalon

\begin{tabular}{|l|c|}
\hline \multicolumn{1}{|c|}{ Rincian } & $\begin{array}{c}\text { Nilai rata-rata } \\
\text { (Rp/musim) }\end{array}$ \\
\hline Penerimaan Total (TR) & 28.925 .000 \\
\hline Biaya Total (TC) & 19.094 .266 \\
\hline Pendapatan= TR -TC & $\mathbf{9 . 8 3 0 . 7 3 4}$ \\
\hline
\end{tabular}

Pendapatan yang diperoleh pedagang pengumpul desa adalah sebesar Rp.9.229.398 per musim. Jika mengacu pada kriteria usaha yang prospek menurut Soeharto (1999), maka dapat dikatakan bahwa usaha ini prospek. Jika dikonversi menjadi pendapatan per bulan adalah sebesar Rp.2.307.349 per bulan. Mengacu pada besaran nilai UMP yang berlaku di Sultra tahun 2014 maka pendapatan yang diperoleh dari usaha pengolahan abalon kering di atas standar upah minimum.

Pendapatan yang diperoleh pedagang pengumpul bersifat fluktuatif yaitu dipengaruhi oleh jumlah produksi dan harga jual abalon kering. Meskipun harga abalon kering cenderung stabil pada tingkat pedagang antar provinsi, tetapi harga bisa turun apabila kualitas abalon yang dijual tidak memenuhi syarat yang diberlakukan oleh eksportir.

\section{Pendapatan dalam Usaha Penjualan Abalon Kering}

\section{Penerimaan}

Berdasarkan hasil penelitian menunjukan bahwa volume penjualan (total produksi) abalon kering (berat bersih) berkisar antara $110-220 \mathrm{~kg}$ per musim. Rata-rata volume penjualan adalah $147 \mathrm{~kg}$ per musim. Harga jual abalon antar provinsi adalah Rp.500.000 per kg. Sehingga penerimaan responden dari usaha ini adalah berkisar antara Rp.54.957.500-Rp.109.915.000 per musim. Rata-rata penerimaan adalah sebesar Rp.73.276.667 per musim. Adanya variasi jumlah penerimaan responden disebabkan karena volume penjualan abalon kering masing-masing responden berbeda-beda. Volume penjualan yang berbeda dipengaruhi oleh pasokan abalon kering dari pedagang pengumpul desa yang juga berbeda-beda.

2. Biaya

Biaya tetap dalam usaha penjualan abalon kering antara lain adalah biaya perawatan dan penyusutan gudang penampungan dan alat-alat yang digunakan dalam pengepakan abalon kering selama satu bulan produksi. Alat-alat yang digunakan 
antara lain adalah timbangan besar dan alat packing. Adapun biaya tidak tetap diantaranya adalah harga abalon kering dari pengumpul, biaya pengiriman, upah tenaga kerja dan biaya lainnya yang dihitung selama satu musim produksi

Besarnya biaya total yang dikeluarkan oleh dalam usaha penjualan abalon kering adalah sebesar Rp.64.733.412 per musim. Komponen biaya tidak tetap secara keseluruhan merupakan biaya terbesar yang dikeluarkan oleh nelayan yaitu 92,27 \% dari keseluruhan biaya yang dikeluarkan. Harga pembelian abalon kering dari pengumpul desa merupakan biaya terbesar yang dikeluarkan pada komponen biaya ini yaitu Rp. 38.566.667 per musim. Sedangkan biaya lain-lain adalah biaya terkecil yang dikeluarkan dalam usaha penjualan abalon kering yaitu Rp.66.667 per musim. Biaya ini berasal dari komponen biaya tidak tetap.

Lebih jelasnya tentang besarnya penggunaan biaya dalam usaha penjualan abalon kering dapat dilihat pada Tabel 7 .

Tabel 7. Rata-rata Penggunaan Biaya Produksi dalam Usaha Penjualan Abalon Kering Oleh Pedagang Antar Provinsi di Kota Kendari, Tahun 2014

\begin{tabular}{|c|r|}
\hline Komponen Biaya & \multicolumn{1}{|c|}{$\begin{array}{c}\text { Nilai rata-rata } \\
\text { (Rp/musim) }\end{array}$} \\
\hline 1. Biaya Tetap per Musim ${ }^{\star}$ ) & $\mathbf{5 . 0 0 3 . 3 3 2}$ \\
\hline - Biaya perawatan & 4.420 .000 \\
\hline - Biaya penyusutan & 583.332 \\
\hline $\begin{array}{l}\text { 2. Biaya Tidak Tetap per } \\
\text { Musim }{ }^{\star} \text { ) }\end{array}$ & $\mathbf{5 9 . 7 3 0 . 0 8 0}$ \\
\hline
\end{tabular}

\begin{tabular}{|l|r|}
\hline - Harga abalon kering & 38.566 .667 \\
\hline - Biaya pengiriman & 563.413 \\
\hline - Upah Tenaga Kerja & 20.533 .333 \\
\hline - Biaya lain-lain & 66.667 \\
\hline 3. Biaya Total & $\mathbf{6 4 . 7 3 3 . 4 1 2}$ \\
\hline
\end{tabular}

Ket: *) satu musim rata-rata empat bulan

3. Pendapatan

Hasil penelitian diketahui bahwa ratarata pendapatan dari hasil pengolahan abalon kering adalah sebesar Rp.8.543.255 per musim. Lebih jelasnya tentang penerimaan total, biaya total dan pendapatan dari usaha penjualan abalon kering di Kota Kendari dapat dilihat pada Tabel 8.

Tabel 8. Pendapatan dari Usaha Penjualan Abalon Kering di Kota Kendari, Tahun 2014

\begin{tabular}{|l|c|}
\hline \multicolumn{1}{|c|}{ Rincian } & $\begin{array}{c}\text { Nilai } \\
\text { rata-rata } \\
\text { (Rp/bulan) }\end{array}$ \\
\hline Penerimaan Total (TR) & 73.276 .667 \\
\hline Biaya Total (TC) & 64.733 .412 \\
\hline Pendapatan= TR -TC & $\mathbf{8 . 5 4 3 . 2 5 5}$ \\
\hline
\end{tabular}

Pendapatan yang diperoleh pedagang antar provinsi dari penjualan abalon kering adalah sebesar Rp.8.543.255 per musim. Pendapatan pedagang antar provinsi cukup tinggi dan jika mengacu pada kriteria usaha yang prospek menurut Soeharto (1999), maka dapat dikatakan bahwa usaha ini prospek Jika dikonversi menjadi pendapatan per bulan adalah Rp.2.135.813 per bulan. 
Jika mengacu pada besaran nilai UMP yang berlaku di Sultra yaitu Rp.1.400.000 per bulan maka pendapatan yang diperoleh dari usaha penjualan abalon kering memenuhi standar upah minimum yang berlaku. Pendapatan ini khusus dari penjualan abalon kering dari pemasok di Kec. Soropia. Kenyataan di lapangan bahwa rata-rata pedagang antar provinsi memiliki lebih dari dua pemasok abalon hasil olahan. Pemasok abalon hasil olahan diantaranya berasal dari Kabupaten Buton, Wakatobi, Menui Kepulauan dan Maluku.

Pendapatan yang diperoleh pedagang antar provinsi juga bersifat fluktuatif yaitu dipengaruhi oleh volume penjualan dan harga jual abalon kering di tingkat eksportir. Volume penjualan abalon kering oleh pedagang antar provinsi ditentukan oleh pasokan abalon kering dari pedagang pengumpul desa. Sedanngkan harga abalon tergantung kualitas abalon kering yang dijual oleh pedagang antar provinsi.

Hal ini menjadi kendala bagi pedagang antar provinsi karena biasanya eksportir meminta pasokan abalon kering dengan jumlah 5 sampai 10 ton dalam satu kali pengiriman. Terkadang membutuhkan waktu yang lama untuk mengirim abalon kering kepada eksportir dengan jumlah yang diminta. Biasanya pedagang antar provinsi menyiasatinya dengan cara membeli abalon kering dari pengumpul di luar wilayah Sultra seperti dari Sulawesi Tengah dan Kepulauan Maluku.

\section{Prospek Agribisnis Abalon di Kabupaten Konawe dan Kota Kendari}

Prospek Agribisnis Abalon di Kabupaten Konawe dan Kota Kendari dideskripsikan dari beberapa aspek yang mendukung pengembangan agribisnis di Kab. Konawe dan Kota Kendari. Aspek-aspek tersebut adalah aspek teknis,ekonomi, finansial dan kebijakan.

\section{Aspek Teknis}

Upaya pembenihan abalon telah dilakukan untuk mendukung kegiatan budidaya. Namun produksi benih yang dihasilkan di balai benih masih dalam skala kecil dengan tingkat keberhasilan 0,5-2 \% dalam satu siklus pemijahan. Tingkat keberhasilan pemijahan menunjukan adanya peningkatan meskipun tidak signifikan. Data yang diperoleh menunjukan bahwa pada tahun 2009 nilai SR (survival rate) abalon hasil pemijahan adalah 0,5-0,8 \%. Pada tahun 20013 nilai SR abalon hasil pemijahan adalah 1,5-2\%. Hal ini menunjukan adanya peningkatan pengetahuan dan keterampilan dalam proses pembenihan abalon.

\section{Aspek Ekonomi}

Aspek ekonomi yang mendukung agribisnis abalon dibatasi pada permintaan pasar dan harga. Produk abalon merupakan komoditi perikanan dunia yang saat ini sedang mengalami peningkatan permintaan terutama dari pasar intenasional. Pasar utama abalon adalah Cina, Jepang, Taiwan, Korea, Singapore, Jepang, Australia, Amerika Serikat, 
Spanyol, Belanda, Kanada, dan Thailand (Cook dan Gordon, 2010).

Data yang diperoleh menunjukan bahwa permintaan terhadap produk abalon di pasar internasional mengalami peningkatan dari tahun 1993 sampai tahun 2007. Lebih jelasnya dapat dilihat pada Tabel 9.

Tabel 9. Persediaan (Supply) dan Permintaan (Demand) Produk Abalon di Dunia

\begin{tabular}{|c|c|c|}
\hline Tahun & $\begin{array}{c}\text { Persediaan/ } \\
\text { Supply } \\
\text { (metrik ton) }\end{array}$ & $\begin{array}{c}\text { Permintaan/ } \\
\text { Demand } \\
\text { (metrik ton) }\end{array}$ \\
\hline 1993 & 7.000 & 19.000 \\
\hline 2004 & 19.000 & 22.000 \\
\hline 2007 & 34.000 & 39.000 \\
\hline
\end{tabular}

(Cook dan Gordon, 2012)

Cook dan Gordon (2012) menyebutkan bahwa harga produk abalon kering di pasar internasional berkisar antara US\$22-44 per kg. Harga tergantung dari kualitas produk abalon yang dihasilkan. Jika telah diolah di restoranrestoran maka harganya bisa mencapai US \$50-60 per porsi (2-3 ekor abalon per porsi).

\section{Aspek Finansial}

Lembaga perbankan belum mendukung pengembangan bisnis abalon misalnya dalam hal pinjaman modal usaha terutama di kalangan nelayan tangkap dan pedagang pengumpul desa. Hal ini dapat diketahui dari sumber permodalan pelaku bisnis abalon yang sebagian besar menggunakan modal sendiri atau bukan pinjaman modal dari bank. Dari 65 orang nelayan penangkap abalon, seluruhnya menggunakan modal pribadi atau keluarga dalam menjalankan usahanya.

Nelayan budidaya menggunakan modal berupa bantuan dari pemerintah Kota Kendari. Dari 4 orang pedagang pengumpul desa, satu orang yang menggunakan modal pinjaman dari bank. Sedangkan dari tiga orang pedagang antar provinsi semuanya menggunakan modal pinjaman dari bank.

\section{Aspek Kebijakan}

Pemerintah Kota Kendari memberi dukungan terhadap pengembangan budidaya perikanan termasuk budidaya abalon. Melalui Dinas Kelautan dan Perikanan bantuan diberikan kepada nelayan di beberapa keluarahan seperti Kelurahan Sambuli dan Kelurahan Purirano untuk pengembangan budidaya abalon. Budidaya abalon yang dikembangkan dengan metode keramba tancap. Bantuan tersebut diberikan dalam bentuk modal usaha sebesar Rp.1,1 milyar. Akan tetapi rincian secara detail berapa bantuan modal usaha untuk budidaya abalon tidak diketahui dengan pasti dalam penelitian ini.

Pemerintah Provinsi Sulawesi Tenggara, melalui Dinas Kelautan dan Perikanan menetapkan kawasan-kawasan konservasi untuk beberapa produk ekonomis seperti abalon Kawasan-kawasan potensial untuk konservasi abalon di Sultra diantaranya adalah Taman Nasional Kepulauan Wakatobi dan 
Pulau Hari Kabupaten Konawe Selatan (Fermin dan Encena, 2009).

Hasil deskripsi dari aspek-aspek di atas dikelompokkan menjadi faktor kekuatan (strength), kelemahan (weakness), peluang (opportunity) dan ancaman (threat) dengan merujuk pada Fermin dan Encena (2009). Secara sederhana pengelompokkannya dapat dilihat pada Tabel 10.

Tabel 10. Faktor Kekuatan, Kelemahan, Peluang dan Ancaman yang Dimiliki dalam Agribisnis Abalon di Kabupaten Konawe dan Kota Kendari, Tahun 2014

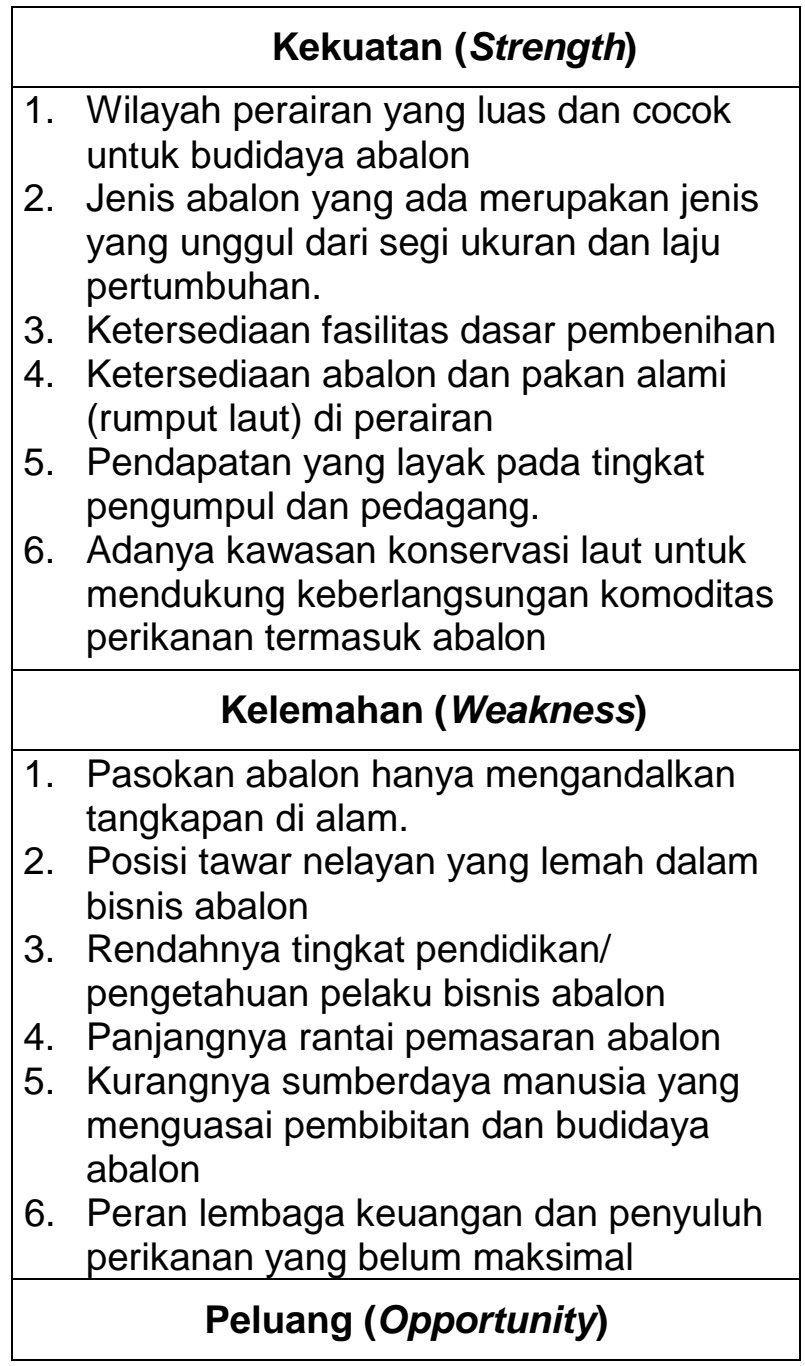

1. Permintaan yang meningkat terutama di pasar ekspor

2. Harga yang tinggi di pasar ekspor

3. Memiliki pangsa pasar tersendiri

4. Peluang kerja bagi masyarakat

5. Membantu meningkatkan pendapatan masyarakat

6. Adanya dukungan pemerintah Ancaman (Threat)

1. Over fishing akibat penangkapan yang berlebihan

2. Konflik penggunaan lahan untuk kegiatan budidaya

\section{KESIMPULAN DAN SARAN}

\section{Kesimpulan}

Berdasarkan pembahasan yang telah diuraikan pada bagian sebelumnya, maka dapat ditarik kesimpulan sebagai berikut:

1. Pendapatan dari usaha penangkapan abalon di Kab. Konawe sebesar Rp.309.211 per musim. Usaha ini tidak prospek karena pendapatan yang diperoleh nelayan tidak memenuhi kriteria dan di bawah nilai Upah Minimum Provinsi (UMP).

2. Pendapatan dari usaha pengolahan abalon oleh pedagang pengumpul desa di Kab. Konawe sebesar Rp.9.830.734 per musim. Usaha ini prospek karena pendapatan yang diperoleh memenuhi kriteria usaha yang prospek dan di atas nilai UMP.

3. Pendapatan dari usaha penjualan abalon kering oleh pedagang antar provinsi di Kota Kendari adalah sebesar Rp.8.543.255 per musim. Usaha ini prospek karena pendapatan yang 
diperoleh memenuhi kriteria usaha yang prospek dan di atas nilai UMP.

4. Agribisnis abalon di Sultra cukup prospek dimana dari segi permintaan dan harga terus mengalami peningkatan, adanya dukungan dari pemerintah, tersedianya layanan jasa pendukung seperti lembaga penelitian, lembaga keuangan dan penyuluhan meskipun belum berperan secara maksimal.

\section{Saran}

Berdasarkan kesimpulan dari hasil penelitian ini, maka dapat diajukan beberapa saran sebagai berikut:

1. Perlu ada kajian tentang laju penuruan stok abalon di alam khususnya di wilayah perairan Kecamatan Soropia serta sosialisasi cara penangkapan abalon yang ramah lingkungan.

2. Perlu ada sosialisasi dan pelatihan kepada nelayan tentang tehnik budidaya abalon yang baik sehingga mengalami resiko kegagalan dan tidak menimbulkan kerugian.

3. Dukungan pemerintah terutama pada subsitem jasa layanan pendukung agribisnis abalon. Dukungan pemerintah dapat berupa bantuan modal kepada pelaku bisnis abalon.
DAFTAR PUSTAKA

Cook, P.A., and H.R. Gordon. 2010. World Abalone Supply, Markets, and Pricing. International Journal of Shellish Research, Vol. 29 No. 3 p. 569-571.

Estes, J.A., D.R. Lindberg, and C. Wray. 2005. Evolution of Large Body Size in Abalones (Haliotis): Patterns and Implications. International Journal of Paleobiology, Vol. 31 p. 591-606.

Fermin, A.C., and V. C. Encena. 2009. Development of Abalone Industry in East Indonesia. International Journal of Australian Centre for International Agricultural Research (ACIAR), Vol.102 p.10-11.

Hadijah, S.B. Andy Omar dan Zainuddin. 2008. Studi Aspek Biologi Abalon Tropis (Haliotis asinina) dari Perairan Kepulauan Spermonde, Sulawesi Selatan. Jurnal IImu Kelautan dan Perikanan Universitas Hasanuddin. Vol.18 No.4, p.286-294.

Heasman, M and N. Savva. 2007. Manual for Intensive Hatchery Production of Abalone: Theory and Practice for YearRound, High Density Seed Production of Blacklip Abalone (H. rubra). Australian Government Fisheries and Development Corporations, Australia. p.108.

KKP. 2010. Peraturan Menteri Kelautan dan Perikanan No:6 Tahun. 2010 Tentang Rencana Strategis Kementrian Kelautan dan Perikanan Tahun 2010-2014. Kementerian Kelautan dan Perikanan Republik Indonesia, Jakarta. 75-79.

Leigh, J., Gurney and N.M. Craig. 2004. Reproductive Biology; Identifyng Spawnig Cycles in The Genus Haliotis. International Journal of Tasmanian Aquaculture and Fisheries Institute, Vol.2 No.3 p. 9-13.

Maliao, R.J., Edward L.W., dan Kathe R.J. 2003. A Survey of Stock of the Donkey's Ear Abalone, Haliotis asinina L. in the Sagay Marine Reserve, Philippines: 
Evaluating the Effectiveness of Marine Protected Area Enforcement. International Journal of Fisheries Research: Elsevier, 66 (2004) 343-353

McBride, S., and F.S. Conte. 1994. California Abalone Acuaculture. Abstracts of California University Letters, 221 (1): 7578.

Mubyarto. 1989. Pengantar Ekonomi Pertanian. Penerbit LP3S, Jakarta.

Soeharjo, A. 1989. Arti dan Ruang Lingkup Agribisnis. Institut Pertanian Bogor. Bogor.

Soeharto. 1999. IImu Usahatani. Penerbit BPFE. Yogyakarta.

Soekartawi, 2010. Agribisnis Teori dan Aplikasinya, PT Raja Grafido Persada. Jakarta.

Stevens, M.M. 2003. Seafood Watch, Seafood Report Cultured Abalone (Haliotis spp.) Abstracts of Fisheries Research Analyst Monterey Bay Aquarium, USA. 210 (1): 10-14.

Sumaila, R.Ussif, C. Anthony and S. Gil. 2007. Topical Problems in Fishery Economics: An Introduction. Journal of Marine Resource Economics, Vol. 21 p.337-340.

Tjasyono, B. dan Bannu. 2003. Dampak ENSO pada Faktor Hujan di Indonesia. Jurnal Matematika dan Sains. Vol. 8 No.1 p. 15-22. 